\title{
The impact of parturition induction with cloprostenol on immunological parameters in the sow colostrum
}

\author{
Karolina Hlavová, Hana Kudláčková and Martin Faldyna* (D)
}

\begin{abstract}
Background: Farrowing induction with prostaglandin F2 analogue cloprostenol is commonly used on commercial farms to manage the timing of farrowing. When labour induction is applied, the questions arise about possible side effects of such a hormonal intervention on physiological processes connected with labour and lactation, including colostral immunity.

Results: In this study, immune cells composition, lysozyme concentration, complement bacteriolytic activity and proinflamatory (GM-CSF2, IL-1 $\beta$, IL-6, a TNFa) and anti-inflammatory (IL-4, IL-10, TGF $\beta 1$ a TGF $\beta 2$ ) cytokines were measured in colostrum samples from sows farrowing naturally (NP) and from sows with farrowing induced using cloprostenol administration on day 113 of gestation (IP). A significantly higher proportion of lymphocytes was found in colostrum of induced sows compared to colostrum of non-induced sows. No significant differences between NP and IP were found in complement activity, in the proportions of granulocytes, macrophages and lymphocyte subpopulations. Lower lysozyme concentration and higher IL-1 $\beta$, IL-6, TGF $\beta 1$ and TNFa concentrations were found in IP sow colostrum compared to colostrum from NP sows.

Conclusions: An increased proportion of colostral lymphocytes can positively influence the cellular immunity transmission from sow to her offspring. On the other hand, a lower lysozyme concentration can adversely affect newborn's intestinal immunity, as well as changes in cytokine concentrations can have an adverse effect on newborn piglet intestinal epithelium development and its defence function.
\end{abstract}

Keywords: Sow, Colostrum, Lymphocytes, Cytokines, Complement, Lysozyme

\section{Background}

Parturition induction using prostaglandin F2 $\alpha$ (PGF2 $\alpha$ ) or its synthetic analogue cloprostenol is a common practice in pig industry $[1,2]$. This animal husbandry intervention has many positive effects on breeding efficiency. Parturition induction on its own decreases variability in gestation length, facilitating the timing of birth. This makes it easier to look after the sow and newborn piglets during the birth and control the sufficient intake of colostrum by all piglets. More careful birth monitoring

\footnotetext{
*Correspondence: faldyna@vri.cz

Veterinary Research Institute, Hudcova 296/70, 62100 Brno, Czech Republic
}

leads to lower number of stillbirths and neonatal mortality [3] and increases total colostrum intake by whole litter [4]. However, in spite of the above mentioned positive effects, questions are arising, whether parturition induction could adversely affect various physiological parameters, e.g. immunoglobulins content, presence of immune cells etc.

For a newborn piglet, colostrum is a vital source of immunologically active substances, which play the main role in piglet's protection against potential infection. Colostrum components also help a newborn piglet to adapt to living conditions after leaving the sterile environment in the uterus. The epitheliochorial placenta of

C C The Author(s). 2020 Open Access This article is licensed under a Creative Commons Attribution 4.0 International License, which permits use, sharing, adaptation, distribution and reproduction in any medium or format, as long as you give appropriate credit to the original author(s) and the source, provide a link to the Creative Commons licence, and indicate if changes were made. The images or other third party material in this article are included in the article's Creative Commons licence, unless indicated otherwise in a credit line to the material. If material is not included in the article's Creative Commons licence and your intended use is not permitted by statutory regulation or exceeds the permitted use, you will need to obtain permission directly from the copyright holder. To view a copy of this licence, visit http://creativecommons.org/licenses/by/4.0/ The Creative Commons Public Domain Dedication waiver (http://creativecommons.org/publicdomain/zero/1.0/) applies to the data made available in this article, unless otherwise stated in a credit line to the data. 
the pig does not allow transmission of antibodies from mother's to piglet's circulation in utero. Therefore, careful attention is given to colostral antibodies. A shortage of colostrum antibodies is life threatening for the newborn piglet [5]. Concerning immunoglobulin G (IgG) concentration in colostrum, the impact of parturition induction was not found in colostrum of primiparous sows [6]. However, lower levels of IgG were found in colostrum of sows with cloprostenol induced parturition as well as in their piglets' sera, compared to sows with noninduced parturition [7].

Besides antibodies, colostrum contains a variety of immune cells and immunologically active compounds which have a direct antimicrobial effect (e.g. complement, lysozyme) or induce and modulate the immune response (e.g. cytokines, growth factors) [8].

Immune cells in porcine colostrum are mainly phagocytes and lymphocytes, out of which $70-90 \%$ are represented by $\mathrm{T}$ cells $[9,10]$. Colostral $\mathrm{T}$ cells show more effector or memory phenotypic features compared to $\mathrm{T}$ cells found in blood [11], are able to migrate into piglet tissues and respond to specific antigen stimulation [12]. Together with cells, colostrum contains many humoral compounds. The main role in humoral immunity is played by complement and lysozyme. The complement system comprises more than sixty components and activation fragments. It is a part of the innate immune system, it defends the body mainly against gram-negative bacteria, removes immune complexes, contributes to organ regeneration and engages $\mathrm{T}$ and $\mathrm{B}$ cells of the adaptive immune response [13]. Many studies have shown the presence of its haemolytic or bactericidal activity in bovine colostrum [14-17]. However, to the author's knowledge, there is no information about the complement content and activity in porcine colostrum. Lysozyme is $1,4,-\beta-\mathrm{N}$-acetylmuramidase, an enzyme, which cleaves the glycosidic bonds in bacterial cell wall peptidoglycans $[18,19]$. It increases the gut resistance and protects against a wide spectrum of gram-positive and gram-negative bacteria (e.g. enterotoxigenic E.coli). The addition of lysozyme to feed leads to increased weight gains with similar results as global subtherapeutic antibiotic use, which is widely being reduced [20,21].

Passively acquired cytokines modulate the secretion of other cytokines by splenocytes and affect the differentiation of the newborn's immune cells [22]. Porcine colostrum contains a substantial amount of transforming growth factor $\beta$ (TGF- $\beta$ ) [23] The presence and the role of other cytokines in porcine colostrum is poorly documented, regardless of their presumable impact on piglet development and immunity.

The aim of this study was to describe the impact of induction of parturition on selected immunological parameters (immune cells, complement, lysozyme, cytokines) in porcine colostrum with regard to their important impact on the newborn piglet immune system development. The proportion of immune cells (granulocytes, macrophages and lymphocytes with their subpopulations), complement bacteriolytic activity, concentration of lysozyme and cytokines - proinflammatory: granulocyte-macrophage colony-stimulating factor 2 (GM-CSF 2), interleukin $1 \beta$ (IL-1 $\beta$ ), interleukin 6 (IL-6) and tumour necrosis factor $\alpha$ (TNF $\alpha)$ and also antiinflammatory: interleukin 4 (IL-4), interleukin10 (IL-10), TGF $\beta 1$ and TGF $\beta 2$ - was determined in colostrum of sows in which parturition was induced by cloprostenol and of those which delivered spontaneously.

\section{Results}

Total leukocyte counts

The analysis of cells based on propidium iodide exclusion indicated mean cell viability of $95.01 \% \pm 4.89$ of isolated cells. The proportion of lymphocytes from all $\mathrm{CD} 45^{+}$leucocytes was significantly $(P=0.0064)$ higher in colostrum of induced sows $(32.0 \% \pm 16.3)$ compared to colostrum of non-induced sows $(13.8 \% \pm 10.5)$. It was compensated by lower percentages of granulocytes $(51.3 \% \pm 15.8$ in induced sows and $54.8 \% \pm 14.2$ in noninduced sows) and macrophages $(12.0 \% \pm 5.0$ in induced sows and $21.3 \% \pm 17.8$ in non-induced sows).

\section{Lymphocyte subpopulations}

The most abundant lymphocyte subpopulation was Tc cells (induced sows: $33.3 \% \pm 8.2$; non-induced sows: $35.8 \% \pm 11.3$ ) followed by $\gamma \delta$ cells (induced sows: $30.8 \% \pm$ 12.2; non-induced sows: $22.7 \% \pm 7.6$ ), DP cells (induced sows: $21.3 \% \pm 9.3$; non-induced sows: $24.8 \% \pm 8.0$ ) and NK cells (induced sows: $11.2 \% \pm 3.8$; non-induced sows: $10.4 \% \pm 6.4$ ), with a relatively low contribution of Th cells (induced sows: $2.1 \% \pm 2.5$; non-induced sows: $2.5 \% \pm 2.4$ ). No significant differences were found in the proportions of lymphocyte subpopulations comparing colostrum from induced and non-induced sows.

\section{Lysozyme concentration}

In samples from sows with induced parturition, the concentration of lysozyme was significantly $(p=0.0032)$ lower $(0.254 \pm 0.082 \mathrm{mg} / \mathrm{ml})$ compared to concentrations found in samples from sows with non-induced parturition $(0.424 \pm 0.167 \mathrm{mg} / \mathrm{ml})$.

\section{Complement activity}

As a measure of the complement activity in colostrum supernatant, a reciprocal of the time of killing $50 \%$ of the bacterial population $\left(\mathrm{h}^{-1}\right)$ was determined. In samples from sows with induced parturition, the complement activity was $1.158 \pm 0.223 \mathrm{~h}^{-1}$ and from sows with non-induced parturition $1.164 \pm 0.211 \mathrm{~h}^{-1}$. There was 
not found any significant difference between samples from induced and non-induced sows.

\section{Cytokines concentrations}

The levels of GM-CSF2, Il-1 $\beta$, Il-4, Il-6, Il-10, TGF $\beta 1$, TGF $\beta 2$ and TNF $\alpha$ were measured in supernatants from all colostrum samples. High variances among different samples were found in concentrations of all cytokines. Increased levels of all measured cytokines were noted in colostrum samples from sows with induced parturition and significantly higher levels of Il- $1 \beta(p=0.0035)$, Il-6 ( $p=$ $0.0155)$, TGF $\beta 1(p=0,0366)$ and TNF $\alpha(p=0.0216)$ were found. Data for all cytokines are summarised in Table 1.

\section{Discussion}

Many studies confirmed the importance of careful supervision of the sow and newborn piglets during parturition and at an early time after. One of the most important tasks is to arrange an equal access to colostrum for all piglets from the litter [3]. More uniform time of parturition as a consequence of induction enables us to concentrate the majority of farrowings into the working hours of the farm staff. Neonatal assistance with colostrum intake supervision and cross-fostering increase the chances for survival of later born and smaller piglets [24]. In spite of these advantages, concerns are arising among breeders and veterinarians as to whether the farrowing induction by cloprostenol affects colostrum quality and potentially the immunity of the piglets. In this study, we focused on selected immunological compounds in colostrum from sows with cloprostenolinduced parturition and from sows with spontaneous farrowing. The studied parameters were: the proportion of immune cells, complement activity, concentration of lysozyme and cytokines.

The colostrum contains substantial numbers of immune cells which are known to be able to act directly in the mammary gland and in piglet intestinal lumen (neutrophils, macrophages), or can, in the early days of life, migrate into the piglet tissues where they can play a role in adaptive immunity $[9,12,25]$. This study demonstrated a significantly higher proportion of lymphocytes in colostrum of sows with induced parturition, maintaining the same lymphocyte subpopulations distribution, from which we can infer that the migration of cells to the mammary gland caused by induction is not selective. As the PGF2 $\alpha$ is able to modulate the expression of chemokines and their receptors [26], the increased proportion of lymphocytes could be explained by possible increased secretion of chemokines which are responsible for the recruitment of cells into the lactating mammary gland $[8,27]$. The ELR+ CXC chemokine gene promoter sequences have DNA binding sites for the inducible transcription factors AP-1, C/EBP and NF-kB, which in turn are regulated by multiple stimuli including endocrine factors such as prolactin, progesterone and inflammatory cytokines (IL-1, TNF-a) [28]. And these factors are also modulated by PGF2 $\alpha$ [29-31]. We also confirmed the data from our previous study [11] that the majority of colostral leukocytes are cytotoxic $\mathrm{T}$ cells. In a mouse model, the majority of colostral cytotoxic $\mathrm{T}$ cells (CTLs) exhibited high levels of the gut-homing molecules $\alpha 4 \beta 7$ and CCR9, but a reduced expression of the systemic homing marker CD62L. Under the same activation conditions, CD8 T cells transferred through colostrum have a superior capacity to produce potent cytolytic and inflammatory mediators when compared to those generated by the breastfed infant [32], which means that the increased proportion of lymphocytes induced by cloprostenol treatment could potentiate the response.

The complement bacteriolytic activity was determined via bioluminescence assay in this study. It was found that the activity was similar in both studied groups. To the authors' knowledge, there is currently no information about the complement activity detection in porcine colostrum. According to Maye [33] the bactericidal activity in bovine milk is higher than in human milk. Similarly, Sakai [34] detected a lower complement activity in porcine sera compared to human sera. Each of the above mentioned authors used a different method of complement activity determination, so itis incomparable in absolute numbers. However, it can help general comparison among species, and further comparative studies of complement activity would be contributive.

According to the results of this study, it was proven that cloprostenol treatment significantly decreases the concentration of lysozyme in colostrum. The mechanism of lysozyme decrease is possibly via cloprostenol induced

Table 1 Cytokine concentrations $(\mathrm{pg} / \mathrm{ml})$ in colostral supernatant from sows with induced parturition (IP, $n=19)$ and with spontaneous non-induced parturition (NP, $n=18$ ). The values are expressed as mean +/-SD. Cytokines showing significant differences $(p \leq 0.05)$ between IP and NP are marked with asterisks

\begin{tabular}{lllllllll}
\hline & GM-CSF2 & IL-1 $\boldsymbol{\beta} *$ & IL-4 & IL-6 & IL-10 & TGF $\boldsymbol{\beta}$ * & TGF $\beta 2$ & TNFa * \\
\hline IP (mean) & 116.09 & 4596.42 & 874.44 & $17,117.67$ & 104.42 & 238.32 & 75.79 & 4469.00 \\
SD & 261.18 & 2850.11 & 738.62 & 9140.57 & 414.50 & 393.73 & 321.55 & 4987.24 \\
NP (mean) & 106.47 & 1936.89 & 464.00 & 9679.33 & 30.51 & 15.78 & 9.89 & 3838.13 \\
SD & 160.28 & 2119.70 & 372.31 & 9900.21 & 93.19 & 65.05 & 40.77 & $12,347.85$ \\
\hline
\end{tabular}


progesterone drop [35] which besides other effects affects lysozyme activity [36]. Lysozyme as an antibacterial enzyme plays a very important role in non-specific immunity and is necessary for complement binding to the secreted IgA [9]. In case of a decreased level of lysozyme, the barrier function of the gut mucosa can be reduced.

The cytokine analysis in this study revealed higher concentrations of IL-1 $\beta$ and TNF $\alpha$ in colostrum from sows with parturition induced by cloprostenol, compared to colostrum from sows with non-induced parturition. It is known that PGF2 $\alpha$ is able to induce acute inflammation including the increase of above mentioned pro-inflammatory cytokines [31]. In human colostrum, IL- $1 \beta$ stimulates the secretion of TNF $\alpha$ by monocytes and helper $\mathrm{T}$ cells, leading to the production of proinflammatory cytokines stimulating macrophages and consequently establishing cellular immunity in newborns [37]. TNF $\alpha$ by itself stimulates mucin secretion in gut epithelia [38]. As opposed to pro-inflammatory cytokines, higher levels of IL- 6 and TGF $\beta 1$ were found in colostrum of sows with IP. Both of them regulate proinflammatory cytokine production [39] and stimulate antibody secretion, mainly mucosal IgA, as in milk cells as in the newborn's intestine [40, 41]. The largest amount of cytokines is absorbed into the offspring circulation before the process designated as gut closure takes place. It is about 1-2 days after birth, at the same time when mammary secretion changes from colostrum to milk [42]. Maternal cytokines transferred to the offspring via colostrum play an essential role as mediators of early response to infection and modulate the immune repertoire of the offspring [22]. It is assumed that TGF $\beta$ plays a physiological role in regulation of postnatal adaptation of the newborn's gastrointestinal tract [23]. Gut mucosa epithelial cells have on their apical surface many receptors which react to cytokines produced by neighbouring cells (e.g. enterocytes, immune cells). In the newborn intestinal mucosa, epithelial cells also respond to cytokines entering the intestinal lumen with colostrum. To give an example, proinflammatory cytokines (IL-1) can potentiate the inflammatory response of gut epithelia [43]. Many studies on cellular lines have described the effect of cytokines on epithelial barrier functions, permeability, proliferation and apoptosis. For instance, proinflammatory TNFa decreases the expression of tight junction proteins and, subsequently, increases epithelial permeability, whilst the anti-inflammatory IL-6 decreases the permeability [44]. Apart from the physical barrier function of the intestinal epithelial cells, their important role is also in the induction of mucosal adaptive immunity which includes cooperation of epithelial cells with antigen presentation cells and lymphocytes resulting in antibody production and cellular immunity [45].
Despite our inability to determine if the changes in immunological parameters are caused by possible reduction of gestation length or unnatural hormonal changes, both caused by cloprostenol induction of farrowing, or most likely by concurrence of these effects, from a practical point of view, for the breeder, the most important fact is that these changes occur. The complexity of the net of mucosal immune responses is very sensitive to changes in cytokine levels and all interventions; in this case, induction of parturition should be applied in compelling circumstances, with adequate knowledge of the side effects and after thorough pros and cons analysis.

\section{Conclusion}

This study confirmed the impact of farrowing induction using cloprostenol on immune parameters, namely the increased proportion of lymphocytes, lower concentrations of lysozyme and of some cytokines.

\section{Materials and methods}

\section{Animals}

In the experiment, 37 multiparous sows (line Topigs 40) of various parity from Czech farms were used. Nineteen sows (mean parity 3.5 , range of parity $2-8$ ) were given $175 \mu \mathrm{g}$ of cloprostenol, an analogue of prostaglandin F2 $\alpha$ (PGF Veyx ${ }^{\circ}$ forte, Veyx-Pharma GmbH, Germany) intramuscularly on day 114 of gestation (induced sows). Eighteen sows (mean of parity 3.1, range of parity 2-8) were not treated (non-induced sows). All parturitions during which the samples of colostrum were taken occurred up to $24 \mathrm{~h}$ after cloprostenol administration. Colostrum samples from non-induced sows were taken only from sows which were farrowing on day 114 or 115 of gestation to maintain the similar length of gestation as induced sows.

\section{Sample collection and cell isolation}

Samples of colostrum $(30 \mathrm{~mL})$ were collected by manual milking at the time interval between the birth of the first and fourth piglet. Colostrum was collected as a mixed sample from different teats. First two front pairs of teats were excluded from sampling to allow suckling of piglets born so far. Also, the first rear pair of teats was excluded to avoid contamination of the sample by dirt from sow's rear legs. The teats were cleaned with $30 \%$ ethanol (Sigma) before milking. Samples were stored at $4{ }^{\circ} \mathrm{C}$ no longer than $2 \mathrm{~h}$ till processed.

Samples were diluted 1:2 in PBS (Lonza) and centrifuged at $600 \times \mathrm{g}$. Supernatants were stored at $-80^{\circ} \mathrm{C}$ for cytokine, lysozyme and complement assays. Pellets were resuspended in PBS and centrifuged once more at $600 \mathrm{x}$ g. Cells were counted (Coulter Counter M4, Coulter Cientifica) and transferred into U-bottomed 96-well 
microtiter plates (BD Biosciences) for flow cytometry immunostaining.

\section{Immunostaining}

Details of mAbs and second-step reagents used in this study are summarized in Table 2 . In each staining step the reagents were incubated for $20 \mathrm{~min}$ at $4{ }^{\circ} \mathrm{C}$. Staining of cell surface markers was performed in two steps: incubation with primary antibodies was followed by a second incubation with isotype-specific secondary antibodies. For the staining of lymphocyte subpopulations, two additional incubation steps for cell surface marker labelling were performed: free binding sites of the goat anti-mouse antibody were blocked by incubation with mouse serum $(10 \mu \mathrm{l}$ per sample). Thereafter, samples were incubated with Zenon labelled antibodies specific for CD3 (see Table 2 for details on antibodies and Zenon). Cell surface marker labelling was performed in a washing and staining buffer (WSB: PBS containing $0.2 \%$ gelatine from cold water fish skin, 1 g $\mathrm{NaN}_{3}$ and $1.84 \mathrm{~g}$ of $\mathrm{Na}_{4}$ EDTA per litre, all reagents from Sigma-Aldrich). Following each incubation step, the cells were washed twice with $200 \mu \mathrm{l}$ WSB. Prior to incubation and following every washing step, the cells were resuspended using a plate shaker. Moreover, single-stain samples for each fluorochrome present in various panels were prepared as compensation controls. Antigens with the highest expected expression density were selected as compensation controls. These were the following: CD3-PE,
CD8-Alexa647, CD4-DyLight405, CD3-PE-TXRD and CD3-Alexa647.

\section{FCM analysis}

Data were acquired using a flow cytometer (BD FACS Aria Fusion; BD Biosciences, USA) and analysed with FACSDiva 6.0 software (BD Biosciences, USA). In each measurement 500,000 events were collected and a percentage of positive cells was analysed. Doublet events were discriminated on the basis of forward scatter integral versus forward scatter peak height (Fig. 1a). Dead cells were excluded from analysis using propidium iodide staining (Fig. 1b). Leucocytes were determined as CD $45^{+}$cells (Fig. 1c). Granulocytes were determined as $\mathrm{CD} 45^{+} \mathrm{CD} 172 \alpha^{+} \mathrm{swc}^{+}$(Fig. 1d), macrophages as $\mathrm{CD} 45^{+} \mathrm{CD} 172 \alpha^{+}$swc $^{-}$(Fig. 1d) and lymphocytes as CD $45^{+} \mathrm{CD} 172 \alpha^{-}$swc $^{-}$. Lymphocyte subpopulations were determined using a different staining panel. In this panel, light scatter characteristics were used for rough determination of the lymphocyte gate and exclusion of debris (Fig. 2a). Whole population (100\%) of lymphocytes was determined as all $\mathrm{CD}^{+}$and/or $\mathrm{CD}^{+}$cells (Fig. 2b). Afterwards, from the all lymphocytes, the percentage of $\gamma \delta \mathrm{TCR}^{+}$cells was determined (Fig. 2c). According to Sinkora et al. [46], $\gamma \delta \mathrm{TCR}^{+}$cells were subdivided into three subclasses based on CD2 and CD8 expression: $\mathrm{CD}^{+} \mathrm{CD}^{+}, \mathrm{CD}^{+} \mathrm{CD}^{-}, \mathrm{CD}^{-} \mathrm{CD}^{-}$(Fig. 2d). Individual subpopulations of $\gamma \delta \mathrm{TCR}^{-}$cells were defined as follows: Th cells: $\mathrm{CD}_{2}^{+} \mathrm{CD} 3^{+} \mathrm{CD} 4^{+} \mathrm{CD}^{-} \gamma \delta \mathrm{TCR}^{-}$; $\mathrm{DP}$ cells:

Table 2 Primary and secondary reagents used for flow cytometry analysis

\begin{tabular}{|c|c|c|c|c|c|}
\hline Antigen & Clone & Isotype & Flourochrome & Labeling strategy & Source of primary antibody \\
\hline \multicolumn{6}{|c|}{ Leukocyte staining panel } \\
\hline CD45 & $\begin{array}{l}\mathrm{K} 252 \\
1 \mathrm{E} 4\end{array}$ & $\lg G 1$ & $\begin{array}{l}\text { Alexa Fluor } \\
647\end{array}$ & $\begin{array}{l}\text { Secondary } \\
\text { antibody }\end{array}$ & A generous gift from Dr. K. Haverson, University of Bristol, UK \\
\hline CD172a & $\begin{array}{l}74-22- \\
15\end{array}$ & $\lg G 2 b$ & $\begin{array}{l}\text { Alexa Fluor } \\
488\end{array}$ & $\begin{array}{l}\text { Secondary } \\
\text { antibody }\end{array}$ & WSU Monoclonal Antibody Center \\
\hline swc8 & MIL3 & $\lg M$ & $\mathrm{PE}$ & $\begin{array}{l}\text { Secondary } \\
\text { antibodyc }\end{array}$ & $\begin{array}{l}\text { A generous gift from Dr. J.K. Lunney, Animal Parasitology Institute, Beltsville, } \\
\text { USA }\end{array}$ \\
\hline \multicolumn{6}{|c|}{ Lymphocyte subpopulations staining panel } \\
\hline CD2 & PG168A & $\lg G 3$ & $\begin{array}{l}\text { Alexa Fluor } \\
488\end{array}$ & $\begin{array}{l}\text { Secondary } \\
\text { antibody }^{\mathrm{d}}\end{array}$ & WSU Monoclonal Antibody Center \\
\hline CD3 & РPТ3 & $\lg G 1$ & PE & Zenon labelinge & BD Biosciences \\
\hline CD4 & $74-12-4$ & $\lg G 2 b$ & DyLight405 & Secondary antibody ${ }^{f}$ & WSU Monoclonal Antibody Center \\
\hline $\mathrm{CD} 8 \mathrm{a}$ & $76-2-11$ & $\lg G 2 a$ & $\begin{array}{l}\text { Alexa Fluor } \\
647\end{array}$ & $\begin{array}{l}\text { Secondary } \\
\text { antibody }^{g}\end{array}$ & WSU Monoclonal Antibody Center \\
\hline YSTCR & PGBL22A & $\lg G 1$ & PE-TXRD & $\begin{array}{l}\text { Secondary } \\
\text { antibody }\end{array}$ & WSU Monoclonal Antibody Center \\
\hline
\end{tabular}

${ }^{a}$ Goat anti-Mouse lgG1-Alexa647, Life Technologies

${ }^{b}$ Goat anti-Mouse lgG2b-Alexa488, Life Technologies

'Goat anti-Mouse IgM- R-Phycoerythrin, Life Technologies

${ }^{\mathrm{d} G o a t}$ anti-Mouse IgG3-Alexa488, Life Technologies

e IgG1-R-Phycoerythrin Zenon labeling kit, Life Technologies

${ }^{f}$ Goat anti-Mouse IgG2b-DyLight405, GeneTex

${ }^{9}$ Goat anti-Mouse IgG2a-Alexa647, Life Technologies

${ }^{\mathrm{h}}$ Goat anti-Mouse IgG1-PE-TXRD, Life Technologies 


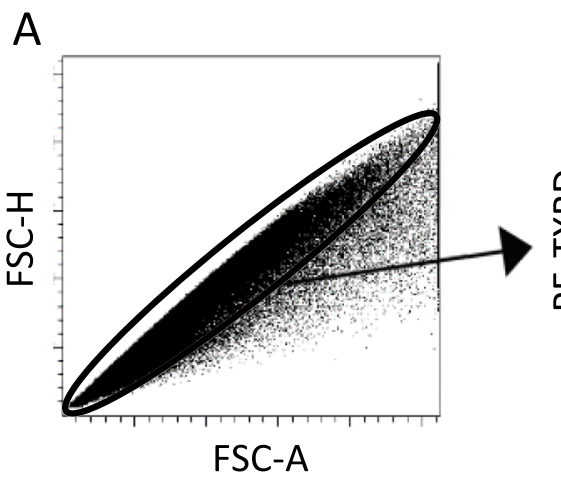

B
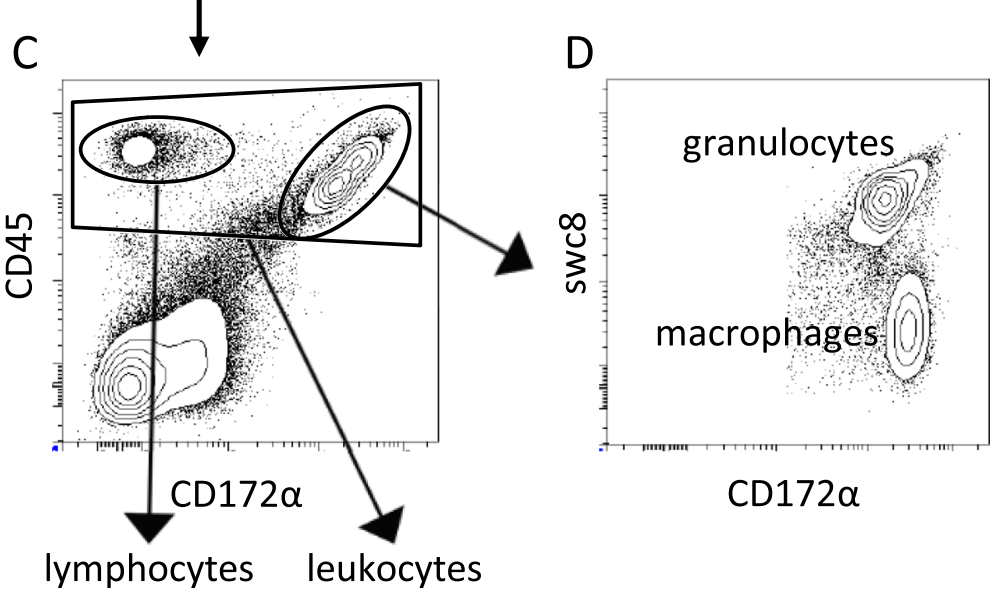

CD172 $\alpha$

Fig. 1 Gating strategy - analysis of leukocyte populations. Doublet events were discriminated on the basis of forward scatter integral versus forward scatter peak height (a). Dead cells were excluded from analysis using propidium iodide staining (b). Leucocytes were determined as CD45 ${ }^{+}$cells (c). Granulocytes were determined as $C D 45^{+} \mathrm{CD} 172 \mathrm{a}^{+}$swc $8^{+}$, macrophages as $\mathrm{CD} 45^{+} \mathrm{CD} 172 \mathrm{a}^{+}$swc $8^{-}$and lymphocytes as $\mathrm{CD}^{2} 5^{+} \mathrm{CD} 172 \mathrm{a}^{-} \mathrm{swC8}^{-}$(d)

$\mathrm{CD} 2^{+} \mathrm{CD} 3^{+} \mathrm{CD} 4^{+} \mathrm{CD} 8^{+} \gamma \delta \mathrm{TCR}^{-}$and $\mathrm{Tc}$ cells: $\mathrm{CD} 2^{+} \mathrm{CD} 3^{+} \mathrm{CD} 4^{-} \mathrm{CD} 8^{\mathrm{hi}} \gamma \delta \mathrm{TCR}^{-}$(Fig. 2f). In addition to $\mathrm{T}$ cells, we also defined NK cells as $\mathrm{CD}^{+}{ }^{+} \mathrm{CD} 3^{-} \mathrm{CD} 4^{-} \mathrm{CD} 8^{\text {lo }} \gamma \delta \mathrm{TCR}^{-}$(Fig. $2 \mathrm{e}$ ).

Lysozyme concentration determination by radial diffusion The amount of lysozyme was assessed in vitro by radial diffusion in agarose gel mixed with Micrococcus luteus (CCM 169). Samples of $20 \mu \mathrm{l}$ of acellular colostrum supernatant from individual sows were applied in duplicates into the wells cut in the agarose placed in glass plates and incubated at room temperature $\left(20^{\circ} \mathrm{C}\right)$. After $24 \mathrm{~h}$, diameter of diffusion zone was measured, and the amount of lysozyme in the sample was converted to milligram per milliliter of colostrum according to the calibration curve (for details see Poisot et al. [47]).

\section{Complement activity determination}

The total bacteriolytic activity was determined using a modified bioluminescence-based method [48-50]. Transformed E. coli $\mathrm{K} 12$ with luxABCDE gene, originating from soil bacterium Photorhabdus, expressing bacterial luciferase (Lux) [51] was used. This Gram-negative bacterium is very sensitive to complement but not to lysozyme as checked before [52]. Bacterial luciferase catalyzes the oxidation of a long-chain aldehyde and the reduced flavin mononucleotide $\left(\mathrm{FMNH}_{2}\right)$ with emission maxima at $490 \mathrm{~nm}$. Bacteria were exposed to acellular colostrum supernatant (diluted 1:2 in PBS) from individual sows. As a negative control, a randomly selected sample of acellular colostrum inactivated at $65^{\circ} \mathrm{C}$ for $10 \mathrm{~min}$ was used. Plasmid of bacteria contains genes for enzyme luciferase and its substrate - long-chain aldehyde. The light emission of the reaction is positively correlated with the viability of $E$. coli which was measured using an LM01-T luminometer (Immunotech, Czech Republic). The time (in hours) required for $50 \%$ viability of $E$. coli was evaluated (in triplicates) using kinetic curves corresponding to complement activity of each sample. There is a reciprocal proportion between time of $E$. coli viability and complement activity; the shorter time represents higher complement activity in colostrum of identical concentration. For 


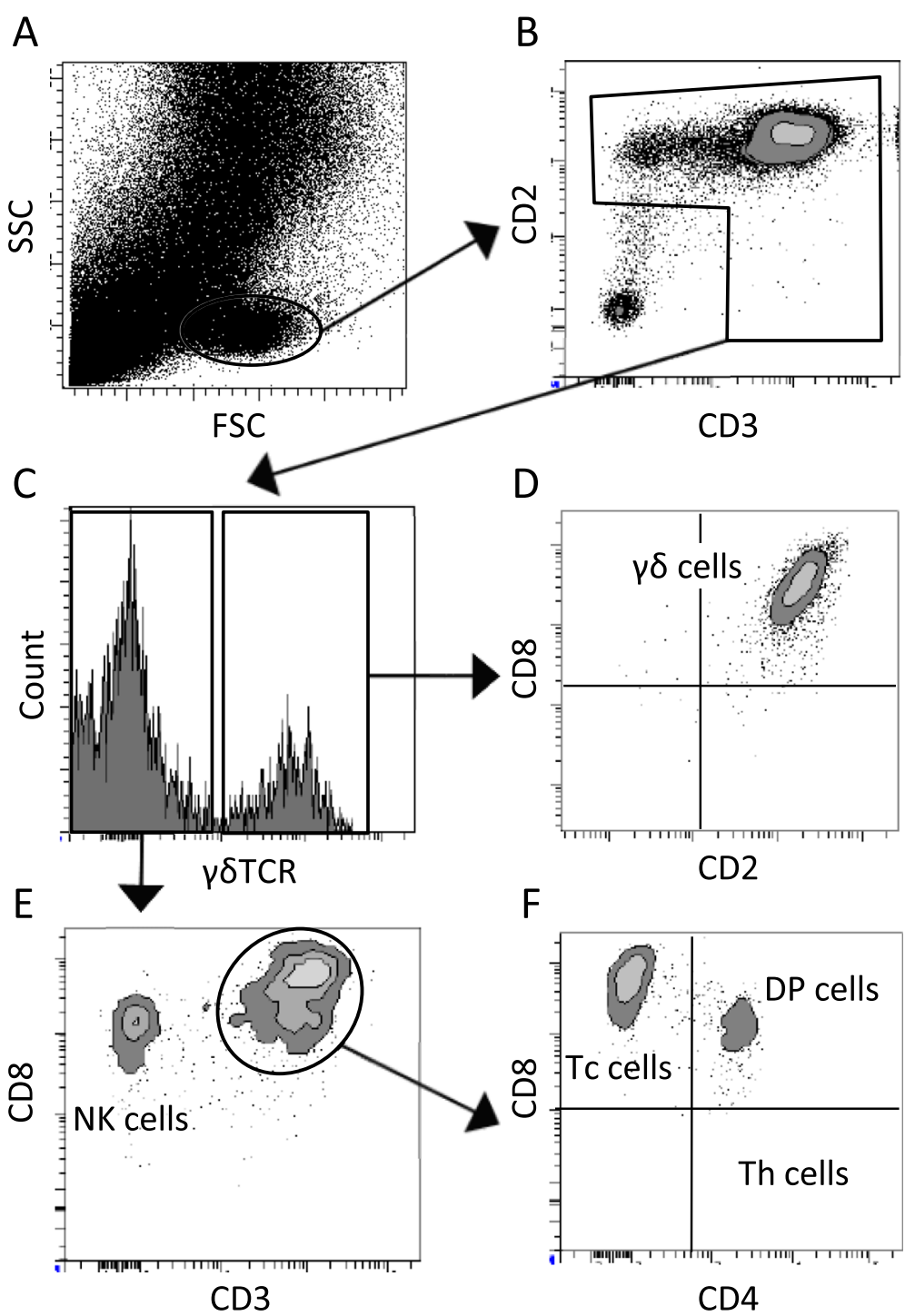

Fig. 2 Gating strategy - analysis of lymphocyte subpopulations. Light scatter characteristics were used for rough determination of the lymphocyte gate and exclusion of debris (a). Lymphocytes were determined as all $\mathrm{CD}^{+}$and/or $\mathrm{CD}^{+}$cells (b). From all lymphocytes, the percentage of $\gamma \delta T C R^{+}$cells ( $\gamma \delta T$ cells) was determined (c). $\gamma \delta T$ cells were subdivided into three subclasses based on CD2 and CD8 expression: $\mathrm{CD}^{+} \mathrm{CD}^{+}, \mathrm{CD}_{2}^{+} \mathrm{CD} 8^{-}, \mathrm{CD}^{-} \mathrm{CD} 8^{-}$(d). Individual subpopulations of $\gamma \delta \mathrm{TCR}^{-}$T cells were defined as follows: Th cells: $\mathrm{CD}^{+} \mathrm{CD}^{+} \mathrm{CD}^{+} \mathrm{CD}^{-} \gamma \delta T C R^{-}$; DP cells: $\mathrm{CD}^{+} \mathrm{CD}^{+} \mathrm{CD}^{+}{ }^{+} \mathrm{CD} 8^{+} \gamma \delta \mathrm{TCR}{ }^{-}$and Tc cells: $\mathrm{CD}^{+} \mathrm{CD}^{+}{ }^{+} \mathrm{CD} 4^{-} \mathrm{CD}^{\text {hi }} \gamma \delta \mathrm{TCR}^{-}$(f). In addition to T cells, we also defined NK cells as $\mathrm{CD}^{+} \mathrm{CD}^{-} \mathrm{CD}^{-} \mathrm{CD} 8^{\mathrm{lo}} \gamma \delta \mathrm{TCR}^{-}(\mathbf{e})$

better comprehension, the complement activity was expressed as inverted values (in $\mathrm{h}^{-1}$ ).

\section{Elisa}

Cytokine concentration was determined by the following ELISA kits: TGF beta 2 Pig ELISA kit, TNF alpha Pig ELISA Kit, Interleukin 6 Pig ELISA Kit, Interleukin $1 \beta$ Pig ELISA Kit, Interleukin 4 Pig ELISA Kit. Interleukin 10 Pig ELISA Kit (all Abcam) and Granulocyte-Macrophage colony-stimulating factor (CSF2) ELISA Kit (CUSABIO). All assays were performed according to the manufacturers' protocols. All the samples were run in duplicates.

\section{Data analysis}

Data are expressed as the mean \pm SD. Statistical analysis was performed with the Mann-Whitney U-test (comparison of cell proportions, lysozyme and complement activity in samples from induced and non-induced sows) and Independent two-sample t-test (comparison of 
cytokine concentrations in samples from induced and non-induced sows) using data analysis software (Statistica, StatSoft, Inc.). The obtained data were considered significant if $P$-values were $P<0.05$.

\section{Acknowledgements}

The authors would like to express their thanks to Jiř Malášek for mediation of sample collection on the farms. Many thanks also go to the staff on the farms, who actively participated in colostrum sampling. The authors also would like to thank Ludmila Faldíková for thorough manuscript proofreading.

\section{Authors' contributions}

The concept and methodology was planned by KH and M.F. Flow cytometric analysis, lysozyme and complement analysis was performed by K.H., ELISA analysis was performed by H.K. The statistical analysis of data did K.H. Original draft wrote K.H. M.F. arranged the funding acquisition. The authors have read and agreed to the published version of the manuscript. All authors read and approved the final manuscript.

\section{Funding}

This study was financially supported by the Ministry of Agriculture of the Czech Republic (projects QJ1510218, RO0518) and the Ministry of Education, Youth and Sports of the Czech Republic (project LO1218 and CZ.1.05/2.1.00/ 19.0385).

\section{Availability of data and materials}

The datasets used during the current study are available from the corresponding author on reasonable request.

\section{Ethics approval and consent to participate}

Not applicable.

\section{Consent for publication}

Not applicable.

\section{Competing interests}

The authors declare that they have no competing interests.

Received: 9 August 2020 Accepted: 19 October 2020

Published online: 11 December 2020

\section{References}

1. Ichikawa H, Koketsu Y. Standard operating procedures for sows and piglets in farrowing and lactation in Japanese commercial herds. J Vet Med Sci. 2012;74:1423-8 http://www.ncbi.nlm.nih.gov/pubmed/22785179 (Accessed 29 Jan 2019).

2. Vanderhaeghe C, Dewulf J, Ribbens S, de Kruif A, Maes D. A cross-sectional study to collect risk factors associated with stillbirths in pig herds. Anim Reprod Sci. 2010;118:62-8. https://doi.org/10.1016/j.anireprosci.2009.06.012.

3. White KR, Anderson DM, Bate LA. Increasing piglet survival through an improved farrowing management protocol. Can J Anim Sci. 1996;76:491-5. https://doi.org/10.4141/cjas96-075.

4. Nguyen K, Cassar G, Friendship RM, Dewey C, Farzan A, Kirkwood RN, et al. An investigation of the impacts of induced parturition, birth weight, birth order, litter size, and sow parity on piglet serum concentrations of immunoglobulin G. J Swine Heal Prod. 2013;21:139-43 http://digital.library. adelaide.edu.au/dspace/handle/2440/79321 (Accessed 21 July 2014).

5. Cabrera RA, Lin X, Campbell JM, Moeser AJ, Odle J. Influence of birth order, birth weight, colostrum and serum immunoglobulin $\mathrm{G}$ on neonatal piglet survival. J Anim Sci Biotechnol. 2012;3:42. https://doi.org/10.1186/2049-18913-42.

6. Foisnet A, Farmer C, David C, Quesnel H. Farrowing induction induces transient alterations in prolactin concentrations and colostrum composition in primiparous sows1. J Anim Sci. 2011;89:3048-59. https://doi.org/10.2527/ jas.2010-3507.

7. Vallet JL, Miles JR, Rempel LA. A simple novel measure of passive transfer of maternal immunoglobulin is predictive of preweaning mortality in piglets. Vet J. 2013;195. https://doi.org/10.1016/j.tvjl.2012.06.009.
8. Salmon H, Berri M, Gerdts V, Meurens F. Humoral and cellular factors of maternal immunity in swine. Dev Comp Immunol. 2009;33:384-93. https:// doi.org/10.1016/j.dci.2008.07.007.

9. Wagstrom E, Yoon K, Zimmerman J. Immune components in porcine mammary secretions. Viral Immunol. 2000;10:153-93 http://www.ncbi.nlm. nih.gov/pubmed/1101660 (Accessed 22 July 2013).

10. Le Jan C. A study by flow cytometry of lymphocytes in sow colostrum. Res Vet Sci. 1994:57:300-4.

11. Hlavova K, Stepanova H, Faldyna M. The phenotype and activation status of T and NK cells in porcine colostrum suggest these are central/effector memory cells. Vet J. 2014;202:477-82. https://doi.org/10.1016/j.tvj.2014.09.008.

12. Nechvatalova K, Kudlackova H, Leva L, Babickova K, Faldyna M. Transfer of humoral and cell-mediated immunity via colostrum in pigs. Vet Immunol Immunopathol. 2011;142:95-100. https://doi.org/10.1016/j.vetimm.2011.03.022.

13. Sarma JV, Ward PA. The complement system. Cell Tissue Res. 2011;343:22735. https://doi.org/10.1007/s00441-010-1034-0.

14. Brock JH, Ortega F, Piñeiro A. Bactericidal and haemolytic activity of complement in bovine colostrum and serum: effect of proteolytic enzymes and ethylene glycol tetraacetic acid (EGTA). Ann Immunol (Paris). 1975;126C: 439-51 http://www.ncbi.nlm.nih.gov/pubmed/813560 (Accessed 30 Jan 2019).

15. Reiter B, Brock JH. Inhibition of Escherichia coli by bovine colostrum and post-colostral milk; 1975. p. 71-82.

16. Eckblad WP, Hendrix KM, Olson DP. Total complement hemolytic activity of colostral whey and sera from dairy cows. Cornell Vet. 1981;71:54-8 http:// www.ncbi.nlm.nih.gov/pubmed/7226847 (Accessed 29 Jan 2019).

17. Korhonen H, Syväoja EL, Ahola-Luttila H, Sivelä S, Kopola S, Husu J, et al. Bactericidal effect of bovine normal and immune serum, colostrum and milk against helicobacter pylori. J Appl Bacteriol. 1995;78:655-62 http:// www.ncbi.nlm.nih.gov/pubmed/7615421 (Accessed 16 Sep 2013).

18. Masschalck B, Michiels CW. Antimicrobial properties of lysozyme in relation to foodborne vegetative bacteria. Crit Rev Microbiol. 2003;29:191-214. https://doi.org/10.1080/713610448.

19. Ellison RT, Giehl TJ, Giehl TJ. Killing of gram-negative bacteria by lactoferrin and lysozyme. J Clin Invest. 1991;88:1080-91. https://doi.org/10.1172/ JCl115407.

20. Oliver WT, Wells JE. Lysozyme as an alternative to growth promoting antibiotics in swine production. J Anim Sci Biotechnol. 2015;6:35. https://doi. org/10.1186/s40104-015-0034-z

21. Huang G, Li X, Lu D, Liu S, Suo X, Li Q, et al. Lysozyme improves gut performance and protects against enterotoxigenic Escherichia coli infection in neonatal piglets. Vet Res. 2018;49:20. https://doi.org/10.1186/s13567-0180511-4.

22. Elahi S, Thompson DR, Van Kessel J, Babiuk LA, Gerdts V. Protective role of passively transferred maternal cytokines against Bordetella pertussis infection in newborn piglets. Infect Immun. 2017;85:1-16. https://doi.org/10. 1128/IAI.01063-16

23. Xu R-J, Doan QC, Regester GO. Detection and characterisation of transforming growth factor-Beta in porcine colostrum. Neonatology. 1999; 75:59-64. https://doi.org/10.1159/000014078.

24. Nguyen KT, Cassar G, Friendship RM, Dewey CE, Farzan A, Kirkwood RN. Stillbirth and preweaning mortality in litters of sows induced to farrow with supervision compared to litters of naturally farrowing sows with minimal supervision. J Swine Heal Prod. 2011;19:214-7 https://www.semanticscholar. org/paper/Stillbirth-and-preweaning-mortality-in-litters-of-Nguyen-Cassar/ 0c227bca081c46e1fe7dff38f7ddd4e91b6de3fb (Accessed 1 Feb 2019).

25. Tuboly S, Bernáth S. Intestinal absorption of colostral lymphoid cells in newborn animals. Adv Exp Med Biol. 2002;503:107-14.

26. Luo W, Diaz FJ, Wiltbank MC. Induction of mRNA for chemokines and chemokine receptors by prostaglandin F2a is dependent upon stage of the porcine corpus Luteum and Intraluteal progesterone. Endocrinology. 2011; 152:2797-805. https://doi.org/10.1210/en.2010-1247.

27. Salmon H. Mammary gland immunology and neonate protection in pigs. Homing of lymphocytes into the MG. Adv Exp Med Biol. 2000;480:279-86. https://doi.org/10.1007/0-306-46832-8_32.

28. Maheshwari A, Christensen RD, Calhoun DA. ELR+ CXC chemokines in human milk. Cytokine. 2003;24:91-102. https:/doi.org/10.1016/..cyto.2003.07.002.

29. Gautvik KM, Kriz M. Effects of prostaglandins on prolactin and growth hormone synthesis and secretion in cultured rat pituitary cells. Endocrinology. 1976;98:352-8. https://doi.org/10.1210/endo-98-2-352.

30. Väänänen JE, Tong BLP, Väänänen $C C M$, Chan $I H H$, Yuen BH, Leung PCK Interaction of prostaglandin F2aand prostaglandin-E2on progesterone 
production in human Granulosa-luteal cells. NeuroSignals. 2001;10:380-8. https://doi.org/10.1159/000046905.

31. Ricciotti E, Fitzgerald GA. Prostaglandins and inflammation. Arterioscler Thromb Vasc Biol. 2011;31:986-1000. https://doi.org/10.1161/ATVBAHA.110. 207449

32. Cabinian A, Sinsimer D, Tang M, Zumba O, Mehta H, Toma A, et al. Transfer of maternal immune cells by breastfeeding: maternal cytotoxic $T$ lymphocytes present in breast Milk localize in the Peyer's patches of the nursed infant. PLoS One. 2016;11:e0156762. https://doi.org/10.1371/journal. pone.0156762.

33. Maye S. Title investigation of the presence and activity of the innate immune component, complement, in bovine milk: University College Cork; 2016. http://hdl.handle.net/10468/3510 (Accessed 7 May 2020).

34. Sakai R, Kitano E, Hatanaka M, Lo P, Matsuura R, Deguchi K, et al. Studies of pig complement: measurement of pig $\mathrm{CH} 50, \mathrm{ACH} 50$, and components. Transplant Proc. 2016;48:1282-4. https://doi.org/10.1016/j.transproceed.2015.10.066.

35. Guthrie HD, Rexroad CE. Blockade of luteal prostaglandin F release in vitro during Cloprostenol-induced Luteolysis in the pig. Biol Reprod. 1980;23:35862. https://doi.org/10.1095/biolreprod23.2.358.

36. Roberts RM, Bazer FW, Baldwin N, Pollard WE. Progesterone induction of lysozyme and peptidase activities in the porcine uterus. Arch Biochem Biophys. 1976;177:499-507. https://doi.org/10.1016/0003-9861(76)90461-6.

37. Brenmoehl J, Ohde D, Wirthgen E. Cytokines in milk and the role of TGFbeta. Best Pract Res Clin Endocrinol Metab. 2018;32:47-56. https://doi.org/ 10.1016/J.BEEM.2018.01.006

38. Fischer BM, Krunkosky TM, Wright DT, Dolan-O'Keefe M, Adler KB. Tumor necrosis factor-alpha (TNF-a) stimulates Mucin secretion and gene expression in airway epithelium in vitro. Chest. 1995;107:133S-5S. https:// doi.org/10.1378/CHEST.107.3_SUPPLEMENT.133S.

39. Garofalo R. Cytokines in human milk. J Pediatr. 2010;156:S36-40. https://doi. org/10.1016/j.jpeds.2009.11.019.

40. Wells JM, Rossi O, Meijerink M, van Baarlen P. Epithelial crosstalk at the microbiota-mucosal interface. Proc Natl Acad Sci. 2011;108:4607-14. https:// doi.org/10.1073/PNAS.1000092107.

41. Ogawa J, Sasahara A, Yoshida T, Sira MM, Futatani T, Kanegane H, et al. Role of transforming growth factor- $\beta$ in breast milk for initiation of lgA production in newborn infants. Early Hum Dev. 2004;77:67-75. https://doi. org/10.1016/J.EARLHUMDEV.2004.01.005.

42. Tizard IR. Veterinary immunology : an introduction. Philadelphia: Saunders; 2004.

43. Chiriac MT, Buchen B, Wandersee A, Hundorfean G, Günther C, Bourjau Y, et al. Activation of epithelial signal transducer and activator of transcription 1 by interleukin 28 controls mucosal healing in mice with colitis and is increased in mucosa of patients with inflammatory bowel disease. Gastroenterology. 2017; 153:123-138.e8. https:/doi.org/10.1053/j.gastro.2017.03.015.

44. Andrews C, McLean MH, Durum SK. Cytokine tuning of intestinal epithelial function. Front Immunol. 2018;9:1270. https:/doi.org/10.3389/fimmu.2018.01270.

45. Oswald IP. Role of intestinal epithelial cells in the innate immune defence of the pig intestine. Vet Res. 2006;37:359-68. https://doi.org/10.1051/vetres:2006006.

46. Sinkora M, Sinkorova J, Holtmeier W. Development of gammadelta thymocyte subsets during prenatal and postnatal ontogeny. Immunology. 2005;115:544-55. https://doi.org/10.1111/j.1365-2567.2005.02194.x.

47. Poisot T, Simková A, Hyrsl P, Morand S. Interactions between immunocompetence, somatic condition and parasitism in the chub Leuciscus cephalus in early spring. J Fish Biol. 2009;75:1667-82. https://doi. org/10.1111/j.1095-8649.2009.02400.x.

48. Virta M, Karp M, Rönnemaa S, Lilius E-M. Kinetic measurement of the membranolytic activity of serum complement using bioluminescent bacteria. J Immunol Methods. 1997;201:215-21. https://doi.org/10.1016/ S0022-1759(96)00225-6.

49. Nikoskelainen S, Lehtinen J, Lilius E-M. Bacteriolytic activity of rainbow trout (Oncorhynchus mykiss) complement. Dev Comp Immunol. 2002;26:797-804. https://doi.org/10.1016/S0145-305X(02)00032-0.

50. Kilpi MK, Atosuo JT, Lilius E-ME. Bacteriolytic activity of the alternative pathway of complement differs kinetically from the classical pathway. Dev Comp Immunol. 2009;33:1102-10. https://doi.org/10.1016/j.dci.2009.06.007.

51. Atosuo J, Lehtinen J, Vojtek L, Lilius E-M. Escherichia coli K-12 (pEGFPluxABCDEamp): a tool for analysis of bacterial killing by antibacterial agents and human complement activities on a real-time basis. Luminescence. 2013;28:771-9. https://doi.org/10.1002/bio.2435.
52. Buchtikova S, Simkova A, Rohlenova K, Flajshans M, Lojek A, Lilius E-M, et al. The seasonal changes in innate immunity of the common carp (Cyprinus carpio). Aquaculture. 2011;318:169-75. https://doi.org/10.1016/j.aquaculture.2011.05.013.

\section{Publisher's Note}

Springer Nature remains neutral with regard to jurisdictional claims in published maps and institutional affiliations.
Ready to submit your research? Choose BMC and benefit from:

- fast, convenient online submission

- thorough peer review by experienced researchers in your field

- rapid publication on acceptance

- support for research data, including large and complex data types

- gold Open Access which fosters wider collaboration and increased citations

- maximum visibility for your research: over $100 \mathrm{M}$ website views per year

At $\mathrm{BMC}$, research is always in progress.

Learn more biomedcentral.com/submissions 